\title{
ДОСЛІДЖЕННЯ ДИНАМІКИ ФОРМУВАННЯ ОСОБИСТІСНИХ ЯКОСТЕЙ МАЙБУТНІХ ТА ПРАКТИКУЮЧИХ МЕДИЧНИХ СЕСТЕР ТА ЇХ МОТИВАЦІЙНИЙ ВПЛИВ У ПРОЦЕСІ ПРОФЕСІЙНОЇ ДІЯЛЬНОСТІ
}

\author{
Л. В. Радецька, І. О. Лаба, А. І. Смачило, К. О. Лопатенко, \\ М. М. Баумер, О. О. Нечаєва \\ Тернопільський національний медичний університет \\ імені І. Я. Горбачевського МОЗ Украӥни
}

\begin{abstract}
Дослідження грунтувалося на результатах клініко-психологічного, психодіагностичного, соціальнодемографічного обстеження студентів медичного коледжу та практикуючих медичних сестер. Виходячи 3 результатів дослідження, вважаємо, що впровадження структурно-діяльнісної моделі розвитку професійних особистісних якостей медичних сестер на першому етапі формування професійної копінгповедінки може використовуватися в незначній модифікації при підготовці не лише медичних сестер, а й інших фахівців, професійна діяльність яких пов’язана з системою відносин «людина - людина».
\end{abstract}

\section{STUDY OF THE DYNAMICS OF FORMATION OF PERSONALITY TRAITS OF FUTURE AND REGISTERED NURSES AND THEIR MOTIVATIONAL INFLUENCE IN THE PROCESS OF THEIR PROFESSIONAL PRACTICE}

\author{
L. V. Radetska, I. O. Laba, A. I. Smachylo, K. O. Lopatenko, \\ M. M. Baumer, O. O. Nechaeva
}

\section{Horbachevsky Ternopil National Medical University}

\begin{abstract}
The study is based on the results of clinical-psychological, psychodiagnostic, socio-demographic assessment of students in medical college and nurses, which work in the hospitals. Based on the results of the study, we believe that the introduction of a structural-activity model of development of professional personality traits of nurses at the first stage of formation of professional coping behavior can be considered as a variant of primary psychoprophylaxis and psychohygiene and can be used in minor modifications during the process of training not only for future nurses, but other professionals whose professional activities are related to the system "human - human".
\end{abstract}

Вступ. Лікувально-профілактичні заклади являють собою основу дієвої системи охорони здоров'я населення України. Якість допомоги, що надають пацієнтам, головним чином залежить від рівня професійної підготовки медичного персоналу, до якого потрібно відносити навички ефективної взаємодії з пацієнтами. Аналіз наукової літератури свідчить, що акцент в усіх дослідженнях зроблений на професії лікаря, проте середній медичний персонал обділений відповідною увагою, адже медичній сестрі частіше, ніж лікарю, доводиться спілкуватися з хворими [1, 2].

Метою дослідження було з'ясувати вплив особистісних якостей на мотивацію, задоволеність професією, а також емоційну спрямованість майбутніх медичних сестер у період навчання, рівень професійних компетенцій практикуючих медичних сестер та динаміку їх змін у процесі взаємодії з пацієнтами.

Основна частина. Дослідження проводили у Харківському обласному медичному коледжі та Комунальному некомерційному підприємстві «Міська клінічна лікарня № 27» Харківської міської ради.

Група досліджуваних склала 96 осіб, з яких 32 студенти - І курсу медичного коледжу зі спеціальності «Медсестринство», 32 - студенти III курсу та 32 - практикуючі медичні сестри.

Середній вік першої підгрупи на момент дослідження склав $(15 \pm 0,8)$ року, другої підгрупи - $(18 \pm 0,9)$ року, третьої підгрупи - $(24 \pm 1,6)$ року.

(ㄱ Л. В. Радецька, І. О. Лаба, А. І. Смачило, К. О. Лопатенко, М. М. Баумер, О. О. Нечаєва, 2021 
Для дослідження уявлень про особистісні якості на кафедрі соціальної гігієни ДВНЗ «Тернопільський державний медичний університет імені І. Я. Горбачевського» розроблено анкету «Критерії особистісних якостей медичних сестер у процесі їх роботи з пацієнтом». Для підготовки анкети на етапі пілотного дослідження опитано 47 викладачів медичних коледжів та досвідчених медичних сестер, котрі мали значний досвід клінічної роботи. Їм було запропоновано записати якості особистості, які, на їх думку, важливі для успішної взаємодії з пацієнтом. їхні відповіді проаналізовано та обрано найчастіші випадки варіантів, які використано в анкеті.

Анкета складалася з 69 критеріїв особистісних якостей. Всі якості віднесено до чотирьох сфер професійної діяльності медичних сестер: практичної, комунікативної, пізнавальної, моральної. Кожну якість респонденти оцінювали за п'ятибальною шкалою.

Отримані відповіді проаналізовано за допомогою методу порівняння середніх за t-критерієм Стьюдента. Результати продемонстрували, що майже за всіма якостями є суттєві статистично достовірні відмінності.

Групи студентів та медичних сестер також отримували анкети «Особистісні якості медичних сестер, які забезпечують взаємодію з пацієнтом» та «Мотиви професійної діяльності лікарів» Н. В. Смирнової, Н. В. Попель. Обробку результатів здійснювали відповідно до інструкцій зі застосування даних методів дослідження. Статистичну обробку матеріалу проводили на персональному комп'ютері з використанням програмних можливостей OFFICE Excel та Stat Plus 2009 Professional. Використовували розрахунок достовірності відмінностей між емпіричними розподілами за критерієм Стьюдента [3, 4].

За результатами дослідження, а саме - про те, які якості медичні сестри вважають найважливішими для ефективної роботи зі своїми пацієнтами, виявлено, що більшість студентів і практикуючих медичних сестер вважають найбільшою цінністю - не втрачати надію на виздоровлення та важливість професійної компетентності, а також на вміння застосувати власний досвід у практичній роботі. Поряд з тим, важливою цінністю медичні сестри визнали вміння професійного спілкування. Інші характеристики, у тому числі професійний розвиток, вміння та навички, емпатія - були визнані медичними сестрами менш важливими. Отже, можна стверджувати, що до першочергових особистісних якостей медичні сестри переважно відносять ті, які пов'язані з якістю їх професійної діяльності та стосунками з пацієнтами (табл. 1).

\section{Табличя 1. Уявлення медичних сестер про найважливіші особистісні якості медичних сестер (у балах)}

\begin{tabular}{|l|c|}
\hline \multicolumn{1}{|c|}{ Особистісні характеристики } & $\begin{array}{c}\text { Медичні сестри, } \\
\text { бал }\end{array}$ \\
\hline Тактовність у спілкуванні & 3,4 \\
\hline $\begin{array}{l}\text { Грамотна мова та добре поставле- } \\
\text { на вимова }\end{array}$ & 4,3 \\
\hline Використання власного досвіду & 4,5 \\
\hline $\begin{array}{l}\text { Вміння пом'якшити негативну для } \\
\text { сприйняття інформацію }\end{array}$ & 4,3 \\
\hline Зберігання медичної таємниці & 4,2 \\
\hline $\begin{array}{l}\text { Вміння проявити турботу до своїх } \\
\text { пацієнтів }\end{array}$ & 4,1 \\
\hline $\begin{array}{l}\text { Прагнення отримати нову профе- } \\
\text { сійну інформацію }\end{array}$ & 4,4 \\
\hline $\begin{array}{l}\text { Досвід вміння моральної підтрим- } \\
\text { ки пацієнта у складній ситуації }\end{array}$ & 3,8 \\
\hline $\begin{array}{l}\text { Вміння надати інформацію доступ- } \\
\text { ну для пацієнта }\end{array}$ & 3,7 \\
\hline $\begin{array}{l}\text { Цікавість до результатів нових } \\
\text { досліджень у медицині }\end{array}$ & 4,2 \\
\hline
\end{tabular}

3 метою дослідження особистісних якостей медичних сестер, ми продіагностували індивідуальнопсихологічні особливості студентів та медичних сестер за допомогою методики «Мотиви професійної діяльності лікарів» Н. В. Смирнової, Н. В. Попель, яка була адаптована до медичних сестер та спрямована на вивчення мотивів вибору та професійної діяльності за медичним фахом. Вибір методики мав на меті встановити, які мотиви домінують у студентів на початку навчання, після завершення та у практикуючих медичних сестер, динаміку цих мотивів у процесі навчання та на різних етапах професійного зростання. Насамперед проаналізували мотиви вибору професії медичної сестри.

Так, статистично важливі відмінності отримали з мотиву «бажання допомагати людям». При цьому найвищий рівень даного мотиву був притаманний студентам I курсу, менш виражений -упрактикуючих медичних сестер, і найнижчий - у випускників. Це можна пояснити тим, що бажання допомагати людям, лікувати їх $є$ основою для вибору спеціальності, тому на початку навчання він максимально високий (рис. 1). До випускного курсу, після отримання досвіду роботи в закладах охорони здоров'я, це прагнення знижується. У той же час, у практикуючих спеціалістів він знову зростає. Це може бути певним захисним 
механізмом підняття значимості своєї праці в умовах, коли ця праця повністю не оцінюється державою в грошовому вираженні.

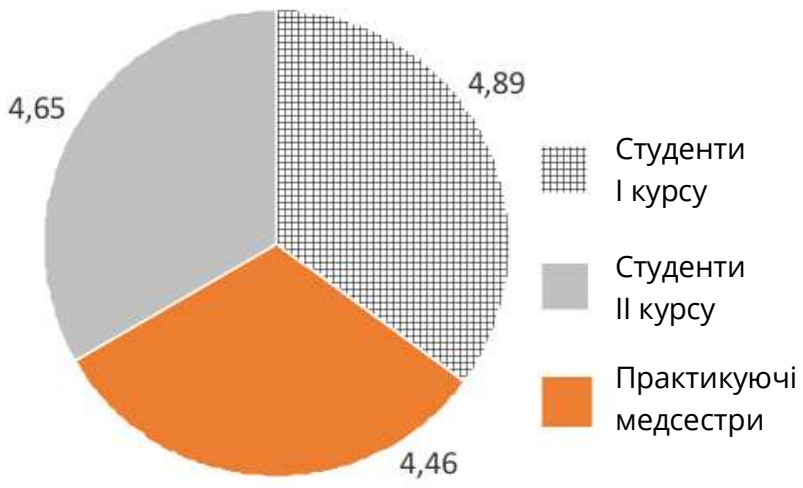

Рис. 1. Результати динаміки мотиву «бажання допомагати людям».

Статистично значимі відмінності виявили і у мотиві «можливість піклуватися про здоров'я близьких» (рис. 2). Ми отримали високі результати вираження цього мотиву в студентів III курсу. Це можна пояснити тим, що на початку навчання можливості допомагати ще немає, але вона з'являється до завершення навчання (отримано достатній багаж знань, інформації), що і позитивно впливає на самооцінку. Нижчі показники у практикуючих медичних сестер, можливо через втому від постійних прохань про допомогу вирішити медичні проблеми від рідних, друзів і знайомих, а також наявність емоційного виснаження.

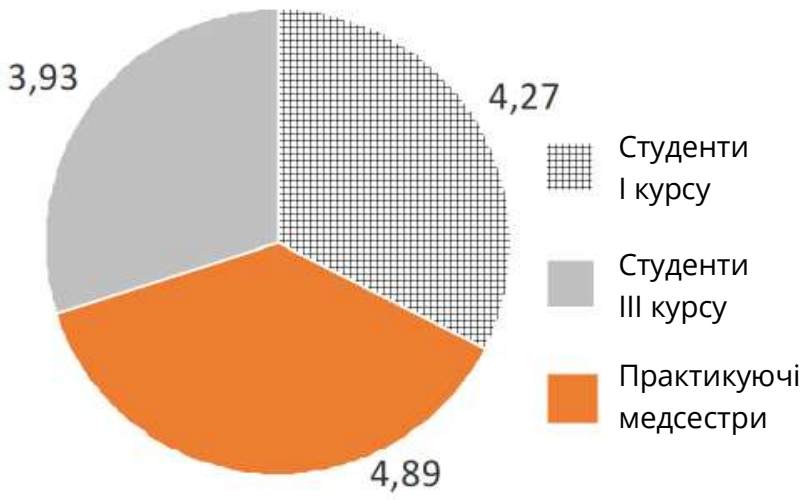

Puc. 2. Динаміка мотиву «можливість піклуватися про здоров'я близьких».

Престиж професії також не однаковою мірою притаманний різним групам досліджуваних. Зокрема, першокурсники мають найвищий рівень вираження цієї мотивації, що може бути пов'язано зі стереотипом, що професія медичного працівника - це благородно і значимо. У процесі навчання та практичної діяльності, все більше заглиблюючись у реалії професії, мотив престижності знижується (рис. 3).

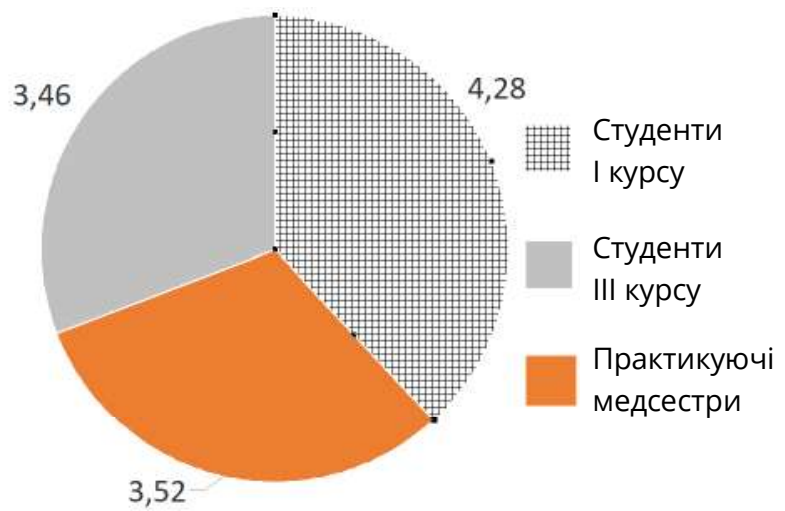

Рис. 3. Динаміка мотиву «престиж професії».

Динаміка мотиву «сімейні традиції» виявилась однією з найцікавіших у нашому дослідженні. Ця мотивація також найбільш виражена у молодшій групі досліджуваних, середній рівень демонструють випускники, але у працюючих вона стає найменш значимою (рис. 4). Можна припустити, що серед абітурієнтів медичних коледжів дійсно багато тих, хто виховувався в родинах медичних працівників і під їх впливом обрав цю професію. Під час навчання таких студентів або відраховують, або у них з'являються більш значимі мотиви, тому до випускного курсу залишається менше студентів, для яких традиції $\epsilon$ важливими. А ще більше зниження ролі традицій серед працюючих через те, що багато випускників вступають на подальше навчання, і меншим чином працюють медичними сестрами.

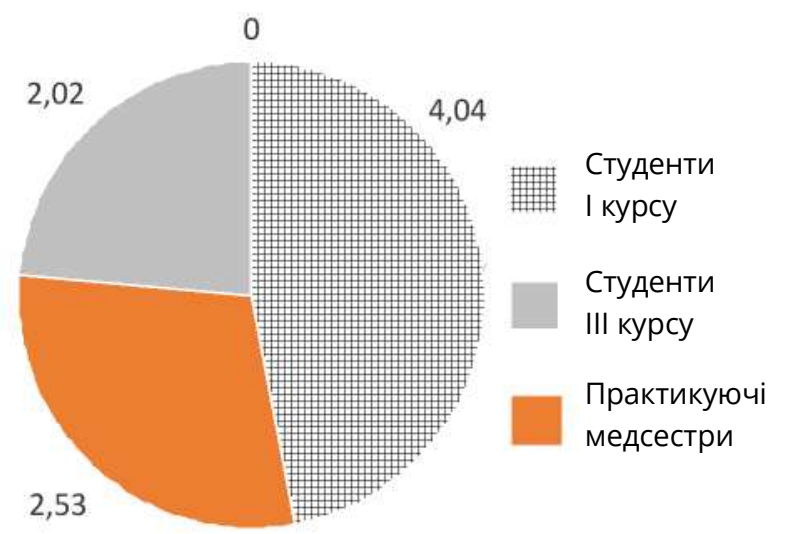

Puc. 4. Динаміка мотиву «сімейні традиції».

Що стосується бажання вирішувати наукові медичні проблеми, як мотивація до навчання та практичної діяльності, то тут низькі показники визначають у всіх трьох групах. Однак у першокурсників вони найниж- 
чі. Це пов'язано з тим, що вкрай невеликий відсоток студентів медичних коледжів бачить себе в науці та хоче приділяти їй свій час. У той же час, у медичних сестер цей показник був достовірно вищим (рис. 5), що пов'язано, на нашу думку, з появою досвіду роботи та освоєння практичних навичок.

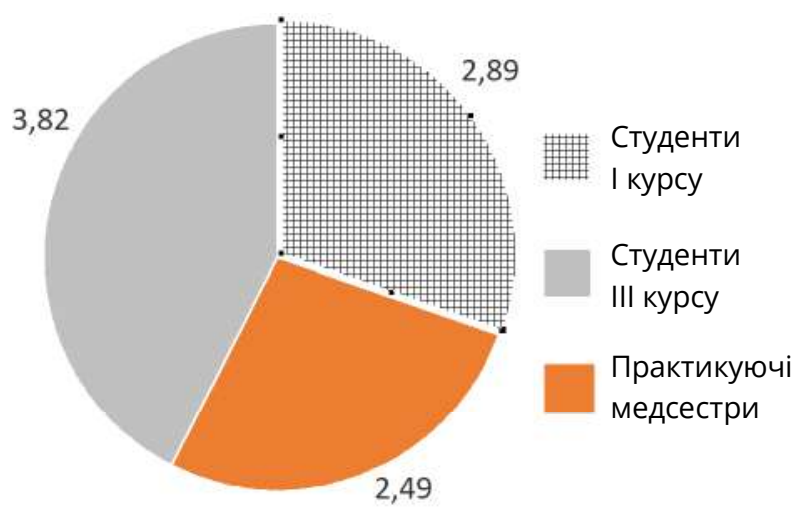

РUс. 5. Динаміка мотиву «бажання вирішувати наукові медичні проблеми».

Суттєві відмінності (високе вираження у студентів та низьке у практикуючих медичних сестер) виявили і в мотиві «турбота про своє здоров'я» (рис. 6). Загальновідомим $є$ факт, що, вивчаючи симптоми та діагностику різних хвороб, студенти починають «приміряти» їх на себе і значною мірою турбуватися про своє здоров'я. У процесі отримання професійного досвіду, хвороби стають звичним явищем і їм не надають такого значення, а іноді на стан свого здоров'я медичний працівник взагалі перестає звертати увагу.

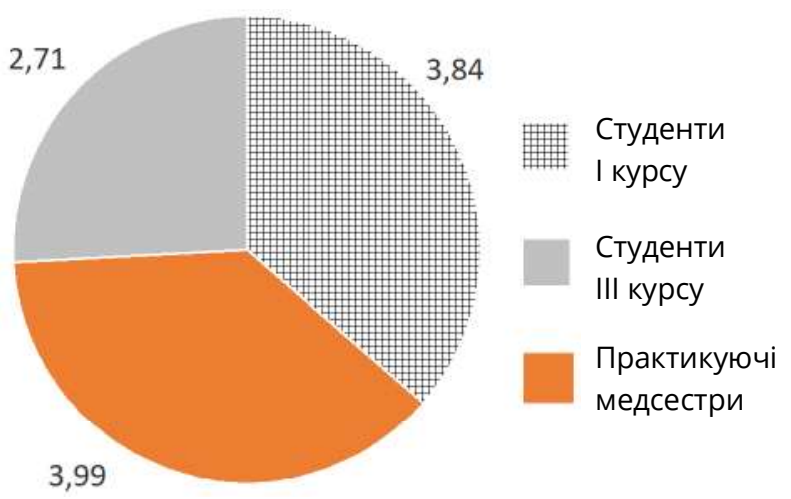

\section{Рис. 6. Динаміка мотиву «турбота про своє здоров'я».}

Також достовірні відмінності виявили за мотивом «матеріальна зацікавленість». Цей мотив $є$ найбільш вираженим у студентів I курсу. Вони ідеалізують майбутню професію, сподіваються на підвищення фінан- сування охорони здоров'я до завершення їх навчання, бачать себе у майбутньому працівниками приватних клінік з достатньо високою заробітною платою. Перед завершенням навчання вони розуміють, що мало що змінилося, тому такий мотив діяльності притаманний випускникам найменше. А от практикуючі медичні сестри вже знаходять джерела додаткового заробітку і рівень цієї мотивації знову зростає (рис. 7).

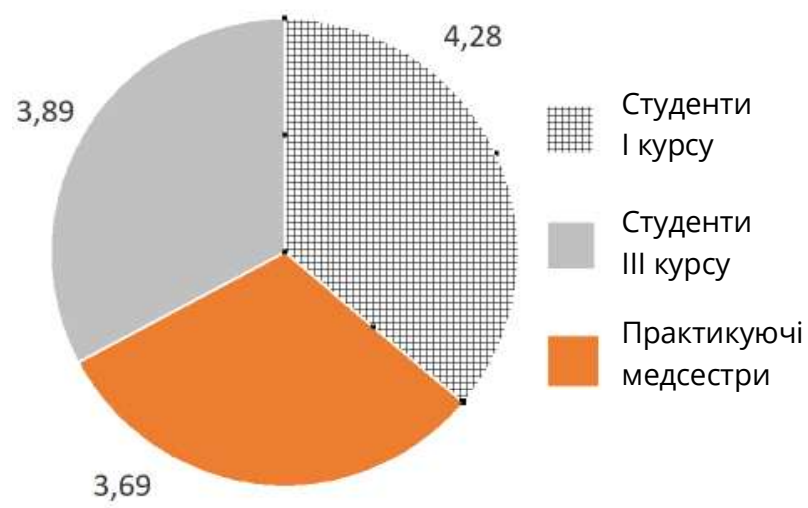

\section{Рис. 7. Динаміка мотиву «матеріальна зацікавленість».}

щодо інших мотивів, то не зафіксували статистично значимих відмінностей між різними групами досліджуваних.

Підсумовуючи вищенаведені дані, можна стверджувати, що якщо у медичної сестри були високі бали за такими мотивами професійної діяльності, як бажання допомагати людям, піклуватися про здоров'я близьких або власне здоров'я, вирішення наукових медичних проблем, то з часом це може призвести до знецінення особистісних якостей. Найбільш негативно на взаємодію в діаді «медична сестра - пацієнт» можуть вплинути мотиви престижу, сімейні традиції та матеріальна зацікавленість. Також вважаємо за необхідне зазначити, що у міру професійного зростання знижується їх значимість. Скоріш за все, це пов'язано з професійним вигоранням.

Основні мотиви, які виявили у досліджуваних медичних сестер, негативно позначаються на ефективності їх взаємодії з пацієнтами. Головним чином це відбувається за рахунок знецінення основних особистісних якостей, що пов'язано з постійним спілкуванням з хворими людьми та ставленням до своєї професії. Проте бажання полегшити страждання тяжкохворих не пов'язане зі зниженням уявлень про значимість будь-яких якостей.

Висновки. 1. На основі проведеного якісного аналізу основних мотивів вибору професії студентів ме- 
дичного коледжу та практикуючих медичних сестер, можна констатувати, що випускникам і практикуючим медсестрам притаманні одні й ті ж мотиви, відмінне лише їхнє місце у ієрархії: так для випускників важливіше допомагати близьким, а для медичних сестер людям взагалі.

\section{СПИСОК ЛІТЕРАТУРИ}

1. Пасєчко Н. В. Основи сестринської справи : підручник / Н. В. Пасєчко, М. О. Лемке, П. Є. Мазур. - Тернопіль : Укрмедкнига, 2002. - 544 с.

2. Закусилова Т. О. Теоретичні засади формування у майбутніх медичних сестер професійної культури як складника професіоналізму / Т. О. Закусилова // Педагогіка і психологія професійної освіти. - 2016. - № 3. - С. 62-68.
2. Дослідження підтвердило тезу про необхідність здійснення професійного відбору серед абітурієнтів медичних коледжів з діагностикою їх мотиваційної сфери та проведення психологічної роботи як під час навчання, так і під час виконання професійних обов'язків.

3. Галян І. М. Психодіагностика: навч. посіб. / І. М. Галян. - К. : Академвидав, 2009. - 464 с. - (Серія «Альмаматер»).

4. Філоненко М. М. Психологія особистісного становлення майбутнього лікаря : монографія / М. М. Філоненко. К. : Центр учбової літератури, 2015. - 334 с. 